\title{
LITERASI GENDER DI KALANGAN MAHASISWA JURUSAN ILMU KOMUNIKASI
}

\author{
RahmawatiHaruna \\ Dosen Jurusan Ilmu Komunikasi UIN Alauddin Makassar \\ Email : rahmawati.haruna@uin-alauddin.ac.id
}

\begin{abstract}
ABSTRAK
Penelitian ini bertujuan menjawab rumusan masalah bagaimana literasi gender dikalangan mahasiswa jurusan Ilmu Komunikasi angkatan 2015 kelompok IKOM A. Metode yang dilakukan dalam penelitian ini adalah kuantitatif dengan menggunakan metode deskriptif. Populasi sekaligus sampel dalam penelitian ini yaitu seluruh mahasiswa jurusan Ilmu Komunikasi pada angkatan 2017 kelompok IKOM A yang berjumlah 38 orang yang tercatat pada semester genap tahun akademik 2016/2017. Data yang diperoleh berdasarkan kategori, diukur dan dihitung menurut frekuensi dan persentasenya. Hasil penelitian menunjukkan bahwa tingkat literasi mahasiswa Ilmu Komunikasi Kelas A masih relative kurang karena tidak disertai dengan upaya lain untuk lebih mengetahui dan mengembangkan wawasan terkait gender seperti halnya aktivitas menulis. Diharapkan hasil penelitian ini menjadi pijakan awal untuk menyosialisasikan, mengembangkan pengetahuan dan pemahaman tentang pentingnya literasi gender di kalangan mahasiswa.
\end{abstract}

\section{PENDAHULUAN}

Terdapat perbedaan mendasar antara kata sex dan kata gender. Sex (jenis kelamin) merupakan pembagian dua jenis kelamin manusia yang ditentukan secara biologis yang melekat pada jenis kelamin tertentu. Adapun gender adalah suatu sifat yang melekat pada kaum laki-laki maupun perempuan yang dikonstruksi secara sosial maupun kultural.

Dalam tatanan kehidupan masyarakat sosial, selama ini ditengarai terdapat ketidakadilan gender baik terhadap kaum laki-laki, terutama terhadap kaum perempuan. Ketidakadilan gender merupakan sistem dan struktur di mana baik kaum laki-laki dan perempuan menjadi korban dari sistem tersebut. ${ }^{1}$ Ketidakadilan gender yang terjadi seringkali menempatkan kaum perempuan sebagai korban dan telah lama menjadi realita di dalam sistem dan struktur kehidupan masyarakat.Hal ini seringkali disebabkan kurangnya pemahaman tentang gender. Berbagai upaya yang telah dilakukan untuk menyebarluaskan konsep gender, namun pihak manapun pasti akan menjumpaihambatan jika tidak ada pemahaman dini terkait gender itu sendiri.

Pemahaman akan gender tidak pandang bulu. Diharapkan semua pihak dapat mewujudkan kehidupan yang setara antara laki-laki dan perempuan atau responsive gender termasuk di kalangan mahasiswa. Hal inilah yang menarik bagi

${ }^{1}$ Mansour Fakih, Analisis Gender dan Transformasi Sosial(Yogyakarta: Pustaka Pelajar, 1996), h. 12. 
peneliti untuk meneliti literasi gender dikalangan mahasiswa jurusan Ilmu Komunikasi Universitas Islam Negeri Alauddin Makassar.

Berdasarkan berbagai uraian latar belakang di atas, maka pertanyaan dalam penelitian ini adalah bagaimana literasi gender dikalangan mahasiswa jurusan Ilmu Komunikasi angkatan 2015 kelompok IKOM A?

\section{TINJAUAN TEORETIS}

\section{Konsep Gender dan Masalah Ketidaksetaraan Gender}

Pada umumnya, masyarakat memahami konsep gender sama dengan jenis kelamin (seks). ${ }^{2}$ Kondisi tersebut memerlukan sebuah ketegasan pandangan, bahwa meskipun memiliki arti kata yang sama, namun keduanya yakni sex dan gender memiliki pengertian yang berbeda.

Gender merupakan konsep sosial yang harus diperankan oleh kaum lakilaki atau perempuan sesuai dengan ekspestasi sosio-kultural yang hidup dan berkembang di tengah-tengah masyarakat yang kemudian melahirkan peran-peran sosial laki-laki dan perempuan sebagai peran gender. Perbedaan peran dan fungsi antara laki-laki dan perempuan itu tidak ditentukan oleh karena keduanya terdapat perbedaan secara biologis. ${ }^{3}$

Namun tidak dapat dipungkiri bahwa cukup banyak peran gender yang sebenarnya memang berlandaskan dari perbedaan biologis. Misalnya, mencuci, memasak, merawat anak yang cenderung diperankan oleh perempuan. Hanya saja menjadi sebuah kekeliruan yang besar bila kita memandang peran tersebut tidak dapat dipertukarkan dan menjadi faktor terjadinya kekerasan gender dalam ruang domestik.

Dalam sejarah kehidupan manusia, ketimpangan gender telah sering terjadi. Ketimpangan tersebut seringkali terjadi baik dari aspek pemikiran dan pemahaman serta aspek sosial keagamaan. ${ }^{4}$ Dalam artian lain, ketidakadilan gender cenderung terjadi hampir di segala lini.

Perbedaan gender sesungguhnya tidaklah menjadi masalah sepanjang tidak melahirkan ketidakadilan gender (gender inequalitas). Namun yang menjadipersoalan, ternyata perbedaan gender telah melahirkan berbagai ketidakadilan, baik bagi kaum laki-laki dan terutama terhadap kaum perempuan. ${ }^{5}$ Kekerasan berbasis gender seringkali menempatkan kaum perempuan sebagai korban atau sebagai kaum yang tersubordinasi.

Dalam rumusan lain, kekerasan dalam rumah tangga didefinisikan setiap perbuatan yang dilakukan oleh seseorang secara sendiri atau bersama-sama terhadap perempuan atau terhadap pihak tersubordinasi lainnya dalam lingkup rumah tangga, yang mengakibatkan kesengsaraan secara fisik, seksual, ekonomi, ancaman psikologis termasuk perampasan kemerdekaan secara sewenangwenang. ${ }^{6}$

Kekerasan berbasis gender dalam bentuk kekerasan dalam rumah tangga merupakan fenomena kebudayaan yang dikonstruk oleh banyak variable antara

\footnotetext{
${ }^{2}$ Ridwan, Kekerasan Berbasis Gender (Pusat Studi Gender, 2006), h. 15.

${ }^{3}$ Ridwan,Kekerasan Berbasis Gender, h. 19.

${ }^{4}$ Syarif Hidayatullah, Teologi Feminisme Islam (Yogyakarta: Pustaka Pelajar,2010), h.1.

${ }^{5}$ Mansour Fakih, Analisis Gender dan transformasi social (Yogyakarta: Pustaka Pelajar, 1996),h. 12.

${ }^{6}$ Ridwan, Kekerasan Berbasis Gender (Pusat Studi Gender, 2006), h. 1.
} 
lain sistem sosial, budaya, hukum dan keyakinan-keyakinan agama. Semua variable tersebut sangat berpengaruh dalam proses pembentukan keyakinan gender. $^{7}$

Semua ketidakadilan gender tersebut, pada dasarnya merupakan refleksi dari ketidakadilan yang terstruktur yang dikonstruk oleh sistem sosial, budaya dan bahkan pula agama yang pada gilirannya merupakan melanggar hak asasi manusia. ${ }^{8}$

Proses terjadinya ketidaksetaraan gender karena perbedaan gender sesungguhnya tidak bisa dilepaskan begitu saja dari perbedaan jenis kelamin (sex) atau biasa juga disebut konstruksi tubuh. Anggapan bahwa misalnya perempuan itu lemah merupakan pandangan yang berlandaskan penilaian dari konstruksi tubuh atau kesan yang ditampilkan berdasarkan seksnya atau berdasarkan analogi tubuh.

\section{Gender dalam Perspektif Islam}

Sejarah awal Islam memaparkan bahwa Islam justru mendorong dan mengangkat kemuliaan perempuan yang belum pernah diberikan sebelumnya oleh suku bangsa manapun dan peradaban tua sebelum Islam. ${ }^{9}$ Hal ini terkait cukup banyaknya sorotan terkait hegemoni Islam terhadap perempuan, khususnya negera-negara islam. Namun hal Islam memang telah memiliki paradigma tersendiri tentang konsep kesetaraan gender tersendiri dan hal-hal apa yang perlu diperujuangkan dalam feminisme Islam.

Menurut Nasaruddin Umar, Islam memiliki banyak prinsip kesetaraan gender, yaitu: Laki-laki dan perempuan sama-sama sebagai hamba, sama-sama sebagai khalifah, sama-sama menerima peranjian primordial yang sama, Adam dan Hawa sama-sama terlibat aktif dalam drama kosmis; serta laki-laki dan perempuan samasama berpotensi meraih prestasi. ${ }^{10}$

Dalam al-quran pula telah diabadikan sosok perempuan seperti Hawa, istri nabi Nuh dan nabi Luth, istri Firaun, Maryam putra Imran, Ratu Bulqis binti Syurahail, ibu nabi Musa as, Zulaikha. ${ }^{11}$ Sosok perempuan yang telah diabadikan dalam al-Quran tersebut tidak dibedakan kecuali tentang persoalan apakah sosok tersebut beriman atau tidak. Sama halnya dengan sosok laki-laki yang diabadikan dalam al-Quran, yang juga tidak dibedakan kecuali berdasakan keimanannya.

Dalam surah an-nisa ayat tujuh, Islam telah mengatur tentang kesetaraan antara laki-laki dan perempuan dalam urusan hak waris, meskipun dalam ketentuan pembagiannya berbeda, namun hal itu diakibatkan dengan alasan tersendiri, dan umat Islam tentunya mengimani ketentuan tentang hak waris tersebut.

Dalam gerakan feminisme, terdapat gerakan feminisme dengan sebutan feminisme islam. Konsep kesetaraan gender yang diperjuangkan adalah menghapuskan diskriminasi gender, terutama yang disebabkan oleh pemahaman

\footnotetext{
${ }^{7}$ Ridwan, Kekerasan Berbasis Gender (Pusat Studi Gender, 2006), h. Vi.

${ }^{8}$ Ridwan, Berbasis Gender,h. 3.

${ }^{9}$ Syarif Hidayatullah, Teologi Feminisme Islam (Yogyakarta: Pustaka Pelajar, 2010), h.

11.

${ }^{10}$ Syarif Hidayatullah, Teologi Feminisme Islam, h. 4.

${ }^{11}$ Noer Huda Noor, Analaisis Kritis Terhadap Ayat-Ayat Gender dalam Al-Qur'an (Makassar: Alauddin University Press, 2012), h. 81-97.
} 
keagamaan yang bias gender. ${ }^{12}$ Hal ini mengingat agama seringkali dilibatkan dalam pembentukan dan pelanggengan hegemoni laki-laki atas perempuan baik dalam ruang publik maupun domestik.

Kajian Hassan menunjukkan bahwa kata Adam dalam ayat-ayat al-Qur'an bukan mengaraha ke makna laki-laki namun merujuk kepada manusia sebagai wakil dari makhluk yang memiliki kesadaran, mengusai ilmu-ilmu pengetahuan. ${ }^{13}$

\section{Literasi}

Literasi berasal dari istilah latin 'literature' dan bahasa inggris 'letter'. Literasi merupakan kualitas atau kemampuan melek huruf/aksara yang di dalamnya meliputi kemampuan membaca dan menulis. Namun lebih dari itu, makna literasi juga mencakup melek visual yang artinya "kemampuan untuk mengenali dan memahami ide-ide yang disampaikan secara visual (adegan, video, gambar).

National Institute for Literacy, mendefinisikan literasi sebagai "kemampuan individu untuk membaca, menulis, berbicara, menghitung dan memecahkan masalah pada tingkat keahlian yang diperlukan dalam pekerjaan, keluarga dan masyarakat." Definisi ini memaknai Literasi dari perspektif yang lebih kontekstual. Dari definisi ini terkandung makna bahwa definisi Literasi tergantung pada keterampilan yang dibutuhkan dalam lingkungan tertentu.

Education Development Center (EDC) menyatakan bahwa Literasi lebih dari sekadar kemampuan baca tulis. Namun lebih dari itu, Literasi adalah kemampuan individu untuk menggunakan segenap potensi dan skill yang dimiliki dalam hidupnya. Dengan pemahaman bahwa literasi mencakup kemampuan membaca kata dan membaca dunia. ${ }^{14}$

Menurut UNESCO, pemahaman orang tentang makna literasi sangat dipengaruhi oleh penelitian akademik, institusi, konteks nasional, nilai-nilai budaya, dan juga pengalaman. Pemahaman yang paling umum dari literasi adalah seperangkat keterampilan nyata - khususnya keterampilan kognitif membaca dan menulis - yang terlepas dari konteks di mana keterampilan itu diperoleh dan dari siapa memperolehnya.UNESCO menjelaskan bahwa kemampuan literasi merupakan hak setiap orang dan merupakan dasar untuk belajar sepanjang hayat. Kemampuan literasi dapat memberdayakan dan meningkatkan kualitas individu, keluarga, masyarakat. Karena sifatnya yang "multiple Effect" atau dapat memberikan efek untuk ranah yang sangat luas, kemampuan literasi membantu memberantas kemiskinan, mengurangi angka kematian anak, pertumbuhan penduduk, dan menjamin pembangunan berkelanjutan, dan terwujudnya perdamaian. Buta huruf, bagaimanapun, adalah hambatan untuk kualitas hidup yang lebih baik. ${ }^{15}$

\footnotetext{
${ }^{12}$ Syarif Hidayatullah, Teologi Feminisme Islam (Yogyakarta: Pustaka Pelajar, 2010), h.27.

${ }^{13}$ Syarif Hidayatullah, Teologi Feminisme Islam (Yogyakarta: Pustaka Pelajar, 2010), h. 37.

${ }^{14}$ Unesco, Literacy, https://www.edc.org/newsroom/articles/what_literacy (5 Juli 2018)

Unesco, Literacy, https://www.edc.org/newsroom/articles/what_literacy (5 Juli 2018)
} 
Pendidikan dan kemampuan literasi adalah dua hal yang sangat penting dalam hidup kita. Kemajuan suatu negara secara langsung tergantung pada tingkat melek huruf di negara tersebut. Orang berpendidikan diharapkan untuk melakukan tugasnya dengan baik.

Dalam sejarah peradaban islam, tradisi literasi islam telah melahirkan tulisan-tulisan para pemikir dan ulama islam klasik yang sudah berumur ratusan tahun sampai saat ini masih eksis dipelajari di berbagai lembaga pendidikan islam, khususnya pesantren. Kitab-kitab yang ditulis para ulama dan intelektual muslim era klasik merupakan sebuah warisan intelektual yang sangat berharga bagi pengembangan khazanah intelektual islam dari generasi ke generasi.

\section{METODOLOGI PENELITIAN}

Jenis penelitian pada penelitian ini adalah kuantitatif dengan menggunakan metode deskriptif. Melalui penelitian ini, peneliti menguraikan secara deskriptif gambaran tentang literasi gender mahasiswa Ilmu Komunikasi khususnya angkatan 2017 kelompok IKOM A.

Populasi sekaligus sampel dalam penelitian ini yaitu sebagai seluruh mahasiswa jurusan Ilmu Komunikasi pada angkatan 2017 kelompok IKOM A yang berjumlah 38 orang yang tercatat pada semester genap tahun akademik 2016/2017. Bagian-bagian data yang diperoleh berdasarkan kategori diukur dan dihitung menurut frekuensi dan persentasenya. Frekuensi adalah dasar umum untuk melakukan perhitungan.

\section{HASIL PENELITIAN}

Secara khusus dalam penelitian yang berkaitan dengan permasalahan yang hendak dikaji menunjukkan identitas responden sebagai berikut:

Tabel 4.1

Karakteristik Responden berdasarkan Jenis Kelamin dan Usia

\begin{tabular}{|c|c|c|c|c|c|}
\hline $\begin{array}{c}\text { Jenis } \\
\text { Kelamin }\end{array}$ & Jumlah & $\%$ & Usia & Jumlah & $\%$ \\
\hline Perempuan & 24 & 63 & $17-19$ & 35 & 82 \\
\hline Laki-laki & 14 & 37 & $20-21$ & 3 & 18 \\
\hline Total & 38 & 100 & Total & 38 & 100 \\
\hline
\end{tabular}

Sumber: Data hasil olahan kuesioner

Data diatas menunjukkan bahwa jumlah responden laki-laki lebih sedikit dibanding perempuan.Data diatas diperoleh dari kelas IKOM A berdasarkan daftar hadir pada semester genap 2016/2017.Usia responden didominasi oleh mereka yang berada pada rentang usia 17-19 tahun,

Tabel 4.2 
Responden Pernah Mendengar Istilah Gender

\begin{tabular}{|c|c|c|}
\hline Jawaban & Jumlah & $\%$ \\
\hline Ya & 36 & 95 \\
\hline Tidak & 2 & 5 \\
\hline Total & 38 & 100 \\
\hline
\end{tabular}

Sumber: Data hasil olahan kuesioner

Istilah gender berdasarkan jawaban responden belum pernah didengarkan oleh 2 responden namun pernah didengarkan oleh hampir seluruh responden atau sebanyak $95 \%$. .

Tabel 4.3

Pemrolehan Istilah Gender

\begin{tabular}{|c|c|c|}
\hline Jawaban & Jumlah & $\%$ \\
\hline Kuliah & 26 & 69 \\
\hline Hasil Baca & 2 & 5 \\
\hline $\begin{array}{c}\text { Mendengar } \\
\text { dari teman }\end{array}$ & 5 & 13 \\
\hline Media Massa & 3 & 8 \\
\hline Tidak tahu & 2 & 5 \\
\hline Total & 38 & 100 \\
\hline
\end{tabular}

Sumber: Data hasil olahan kuesioner

Sejalan dengan pertanyaan apakah responden pernah mendengar atau tidak, jawaban responden terkait sumber pemrolehan informasi beragam. Sebanyak 26 responden menjawab memperoleh istilah gender dari perkuliahan. Mahasiswa IKOM A mengakui telah mengikuti mata kuliah Komunikasi dalam Perspektif Gender, sehingga tahu akan istilah ini. Namun responden lainnya menjawab memperoleh dari hasil baca sebanyak 5\%atau 2 responden, 5 responden memperoleh dari hasil mendengar dari teman, 3 responden atau 8\% dari media massa dan dua responden karena mereka tidak pernah mendengar istilah ini, maka mereka menjawab tidak tahu.

Tabel 4.4

Pemahaman Istilah Gender

\begin{tabular}{|c|c|c|}
\hline Jawaban & Jumlah & $\%$ \\
\hline Paham & 25 & 66 \\
\hline Tidak paham & 13 & 34 \\
\hline Total & 38 & 100 \\
\hline
\end{tabular}

Sumber: Data hasil olahan kuesioner

Tahu belum menandakan paham. Demikian halnya dengan responden pada penelitian ini. Meskipun tahu namun tidak berarti mereka paham akan istilah gender tersebut. Sebanyak $66 \%$ menjawab mereka memahami istilah gender dan $34 \%$ menjawab tidak paham. Berbeda dengan hasil sebelumya pada table 4.3 yang menunjukkan bahwa 36 responden menjawab tahu istilah gender.

Tabel 4.5 
Pentingnya Mengetahui dan Memahami Istilah Gender

\begin{tabular}{|c|c|c|}
\hline Jawaban & Jumlah & $\%$ \\
\hline Penting & 22 & 58 \\
\hline Tidak penting & 16 & 42 \\
\hline Total & 38 & 100 \\
\hline
\end{tabular}

Sumber: Data hasil olahan kuesioner

Namun pemahaman responden yang tahu istilah gender tidak sejalan dengan jawaban mereka yang menganggap penting mengetahui dan memahami istilah gender itu sendiri. Hanya 22 responden yang menjawab penting dan sekitar $16 \%$ menjawab tidak penting.

Tabel 4.6

Menulis Tentang Gender

\begin{tabular}{|c|c|c|}
\hline Jawaban & Jumlah & $\%$ \\
\hline Ya & 0 & 0 \\
\hline Tidak pernah & 38 & 100 \\
\hline Total & 38 & 100 \\
\hline
\end{tabular}

Sumber: Data hasil olahan kuesioner

Literasi mahasiswa Ikom A juga dapat dilihat dari keinginan mereka menulis ide tentang gender.Seluruh mahasiswa IKOM A tidak pernah menulis tentang gender. Hal ini menandakan kurangnya minat mereka menulis dan mengembangkan pemahaman mereka tentang gender.

Tabel 4.7

Pengetahuan Tentang Ketimpangan Gender

\begin{tabular}{|c|c|c|}
\hline Jawaban & Jumlah & $\%$ \\
\hline Tahu & 28 & 74 \\
\hline Tidak tahu & 10 & 26 \\
\hline Total & 38 & 100 \\
\hline
\end{tabular}

Sumber: Data hasil olahan kuesioner

Pengetahuan mahasiswa IKOM A terhadap ketimpangan gender dapat dikatakan baik, oleh karena sebanyak 28 responden atau $74 \%$ menjawab tahu tentang adanya ketimpangan gender. Hanya 10 yang menjawab tidak tahu. Ketimpangan gender yang diketahui oleh responden diantaranya ketidakadilan dalam memperlakukan perempuan dan laki-laki dalam hal memberikan pekerjaan. Perempuan dianggap hanya layak bekerja di wilayah domestic dan tidak cocok pada wilayah pemerintahan atau sector public.

\section{PEMBAHASAN}


Adanya pandangan dan anggapan yang melihat peran antara perempuan dan laki laki cenderung patriakri, perempuan adalah makhluk yang lemah, telah menyebabkan masyarakat melegitimilasi dan menerapkan pemikiran tersebut dalam kehidupan sehari-hari yang akhirnya menimbulkan dampak yang tidak baik seperti meminggirkan hak hak perempuan, pemberian citra negatif terhadap perempuan, pemberian beban yang berlebihan pada perempuan rumah tangga, serta terjadinya KDRT

Sangat penting menciptakan dan membangun kesetaraan peran gender (laki laki dan perempuan) sejak dini. Langkah kesadaran tersebut merupakan bagian penting dalam pendidikan. Oleh karena itu seorang pendidik perlu memiliki wawasan yang luas tentang keadilan gender agar tidak hanya terjadi transfer pendidikan secara kognitif tetapi menanamkan nilai nilai kehidupan khususnya keadilan gender.Sensitif gender dapat dipahami sebagai suatu sikap, baik itu dalam bentuk perkataan maupun perbuatan yang mendukung kesetaraan gender, dan sangat menghindari diskriminasi atas jenis kelamin tertentu.

Pengenalan gender tidak hanya pada tingkatan usia dini namun juga dilakukan hingga level universitas. Di Jurusan Ilmu Komunikasi UIN Alauddin misalnya, pengenalan ataupun penguatan gender dillakukan melalui pemberian mata kuliah Komunikasi Gender.Mata kuliah ini diberikan pada mahasiswa semester awal dengan harapan mereka memperoleh gambaran dan penguatan yang dapat terimplementasi dalam kehidupan sehari-hari.

Sejalan dengan jawaban responden penelitian yang mengungkapkan bahwa istilah gender telah mereka peroleh pada saat mengikuti perkuliahan Komunikasi Gender. Jawaban ini mengindikasikan bahwa istilah gender baru responden peroleh pada saat dibangku kuliah, tidak banyak yang memperoleh istilah atau pengetahuan soal gender dari membaca. Hal ini menunjukkan pula tingkat ketertarikan responden pada topic ini dapat dikatakan kurang karena hanya dua responden yang mengetahui soal gender dari membaca. Demikian pula dengan media massa, hanya dua responden yang menjawab. Namun sangat disayangkan meskipun dengan angka yang kecil masih terdapat responden yang belum tahu tentang gender.

Namun tahu tentang gender tidak berarti dipahami oleh para responden. Dalam penelitian ini, tahu dalam tataran istilah sesuai dengan definisi sederhana istilah gender. Pemahaman dalam penelitian ini berarti kemampuan untuk menjelaskan konsep gender tidak terbatas pada definisi saja, tetapi dapat memberikan pandangan yang lebih luas apakah masalah ketimpangann gender, penyebab ketimpangan gender maupun bagaimana gender disosialisasikan pada segala tingkatan usia dan level masyarakat. Jumlah responden yang paham tentang gender berkurang dari jumlah responden yang tahu tentang gender.

Demikian halnya dengan pengetahuan dan pemahaman responden tidak berarti para responden merasa penting mengetahui dan memahami istilah gender ini.Hanya 22 responden yang menjawab bahwa hal ini penting untuk mereka pahami.

Ketertarikan, motivasi mengetahui dan memahami konsep gender pun terlihat kurang menggembirakan pada mahasiswa IKOM A, hal ini nampak dari jawaban responden yang tidak satupun menjawab pernah menulis soal gender. Asumsi yang dimiliki peneliti bahwa kemampuan dan ketertarikan membaca akan mampu menggairahkan motivasi menulis soal gender para responden. Namun ternyata hal 
ini tidak terjadi pada penelitian ini. Hal yang terjadi adalah adanya korelasi pemrolehan responden dari membaca yang hanya dua orang dengan kemauan menulis soal gender yang sama sekali tidak satu pun responden pernah melakukannya. Padahal Kemampuan literasi dapat memberdayakan dan meningkatkan kualitas individu, keluarga, masyarakat.Literasi sebagai kemampuan baca-tulis merupakan pintu utama bagi pengembangan makna literasi secara lebih luas.

Melalui pertanyaan yang terkait ketimpangan gender, pada umumnya responden menjawab tahu adanya ketimpangan gender. Beberapa responden mengetahui bahwa ketimpangan gender masih terus terjadi dalam berbagai bentuk. Melihat bahwa diskriminasi gender berlangsung sejak awal kehidupan, maka upaya untuk mewujudkan kesetaraan gender adalah langkah pertama yang penting. Selama ini pendekatan gender sebagai milik dan urusan individu ke pendekatan yang melihat pada konteks struktural-kultural yang mendasari perbedaan gender. Hal inilah yang kemudian dikenal dengan kebijakan yang sensitive gender.

Upaya ini hendaknya didahului oleh suatu "kepekaan" yang disebut sebagai "kepekaan gender". Kepekaan gender perlu diikuti oleh "kesadaran gender". Kepekaan dan kesadaran gender merupakan dasar untuk memahami secara lebih mendalam dan menyeluruh permasalahan.

Sejalan dengan hal tersebut, kepekaan dan kesadaran gender seperti yang telah dikemukakan pada bagian sebelumnya bahwa dalam gerakan feminisme, terdapat gerakan feminisme dengan sebutan feminisme islam. Konsep kesetaraan gender yang diperjuangkan adalah menghapuskan diskriminasi gender, terutama yang disebabkan oleh pemahaman keagamaan yang bias gender. Hal ini mengingat agama seringkali dilibatkan dalam pembentukan dan pelanggengan hegemoni laki-laki atas perempuan baik dalam ruang publik maupun domestik.

Kajian Hassan menunjukkan bahwa kata Adam dalam ayat-ayat al-Qur'an bukan mengaraha ke makna laki-laki namun merujuk kepada manusia sebagai wakil dari makhluk yang memiliki kesadaran, mengusai ilmu-ilmu pengetahuan.

Berdasarkan keseluruhan jawaban responden penelitian maka dapat disimpulkan bahwa tingkat literasi mahasiswa Ilmu Komunikasi Kelas A masih relative kurang karena tidak disertai dengan upaya lain untuk lebih mengetahui dan mengembangkan wawasan terkait gender seperti halnya aktivitas menulis. Oleh karena literasi tidak hanya pada tataran tahu tetapi juga aktivitas mendengar, membaca dan menimplementasikannya pada kehidupan nyata.

\section{Kesimpulan}

Berdasarkan hasil penelitian maka dapat disimpulkan bahwa tingkat literasi mahasiswa Ilmu Komunikasi Kelas A masih relative kurang karena tidak disertai dengan upaya lain untuk lebih mengetahui dan mengembangkan wawasan terkait gender seperti halnya aktivitas menulis. Oleh karena literasi tidak hanya pada tataran tahu tetapi juga disertai dengan aktivitas mendengar, membaca dan menimplementasikannya pada kehidupan nyata.. Diharapkan hasil penelitian ini menjadi pijakan awal untuk menyosialisasikan, mengembangkan pengetahuan dan pemahaman tentang pentingnya literasi gender di kalangan mahasiswa. 


\section{DAFTAR PUSTAKA}

Mansour, Fakih.Analisis Gender dan Transformasi Sosial. Cet. XIV; Yogyakarta:Pustaka Pelajar, 2012.

Bourdieu, Pierre. Dominasi Maskulin. Cet. I; Yogyakarta: Jalasutra, 2010.

Ananta Toer, Pramoedya. Arus Balik. Cet. V; Hasta Mitra: Jakarta,1995.

Ananta Toer, Pramoedya.Jejak Langkah. Cet. IV; Hasta Mitra: Jakarta, 2002.

Daud Ibrahim, Marwah, dkk, Wanita dan Media. Cet. Bandung: PT Remaja Rosdakarya, 1998.

Halik,Abdul. Komunikasi Massa. Cet. I; Makassar: Alauddin University Press, 2013.

McQuail, Denis. Teori Komunikasi Massa. Cet. II; Jakarta: Erlangga, 1987.

Ridwan, Kekerasan Berbasis Gender. Cet. I; Pusat Studi Gender, 2006.

Hidayatullah, Syarif. Teologi Feminisme Islam. Cet. I; Yogyakarta: Pustaka Pelajar, 2010.

D. Kristof, Nicholas dan Sheryl Wudunn.Half The Sky .Cet. I; Jakarta: PT Gramedia, 2010.

Nunuk P. Murniati, A. Getar Gender. Cet. I; Magelang: Indonesiatera, 2004.

F. Awuy, Tommy . Wanita dan Media. Cet. Bandung: PT Remaja Rosdakarya, 1998.

Eriyanto, Analisis Wacana. Cet. Yogyakarta: LkiS Group, 2001.

Sobur,Alex.Analisis Teks Media. Cet. Bandung: PT Remaja Rosdakarya, 2006.

Bungin, Burhan. Penelitian Kualitatif, Cet. II; Jakarta: Pernada Media Group, 2008.

J. Moleong, Lexy. Metodologi Penelitian Kualitatif. Cet. XVI; Bandung: Rosdakarya, 2001.

Kurnia Sari, Siti. "Konsep Gender dalam Film Ummi Aminah". Skripsi. Yogyakarta: Fakultas Dakwah dan Komunikasi UIN Sunan Kalijaga, 2015.

Utami, Tri. "Gambaran Perempuan Dalam Film Berbagi Suami". Skripsi. Yogyakarta: Fakultas Dakwah dan Komunikasi UIN Sunan Kalijaga, 2009.

Khaerunnisa Muktadir, Andini. "Konstruksi Cantik dalam Novel After Dark Karya Haruki Murakami”. Skripsi. Makassar: Fakultas Ilmu Sosial dan Ilmu Politik Universitas Hasanuddin, 2016.

Cahya Sari,Eryne. "Produksi Pesan Wayang Klasik dalam Novel Grafis" Skripsi. Surakarta: Fakultas Ilmu Sosial dan Ilmu Politik Universitas Sebelas Maret, 2016.

Ariyani, Isma. "Representasi Nilai Siri' Pada Sosok Zainuddin Dalam Novel Tenggelamnya Kapal Van Der Wijk" Skripsi. Makassar: Fakultas Ilmu Sosial dan Ilmu Politik Universitas Hasanuddin, 2012.

Pustaka Online

Sumber online

Unesco, Literacy, https://www.edc.org/newsroom/articles/what_literacy (5 Juli 2018) 